\title{
Analysis of Change in the Corporate Sphere of the Czech Republic
}

\author{
Tsolmon Jambal ${ }^{1, *}$, Jaroslav Stuchlý ${ }^{1}$ \\ ${ }^{1}$ Institute of Technology and Business, Faculty of Corporate Strategy, Okružní 517/10, 37001 České Budějovice, Czech Republic
}

\begin{abstract}
This contribution presents research into the changes taking place in companies in the Czech Republic. The aim was to determine whether companies in the Czech Republic are undergoing fundamental changes, what influences are forcing them to change, and whether managers prefer radical changes to incremental improvements. The research was carried out in the form of a questionnaire survey, which consisted of four sections and 60 questions, conducted by teachers and students of VSTE in České Budějovice in 2019. The article analyses the characteristics of the selected statements and examines the interdependencies between the variables, including the dependence on the identified identification variables. Keywords: change, radical change, incremental improvement, urgency of change, influence of surroundings
\end{abstract}

\section{Introduction}

There are many publications in scientific literature that deal with change management. However, although the issue of change management dates back to the middle of the 20th century, it only recently began to appear in literature published in the Czech Republic. In the Czech Republic, for example, Častorál [1], Kubíčková and Rais [2], Machan [3], Veber [4], Řehoř [5] Bauer and Hauriová [6] and others deal with the issue of change management. In the Czech Republic, the theoretical literature on change management and organizational change has only come to the fore among experts and the public in the last decade. Veber et al. [4] define change management as a complex of management activities that lead to a shift in an individual, team, department, entire organization from the current state to a state required in the future. Řehoř [5] considers change management as a methodology, process, and professional discipline that should facilitate and accelerate the course of change by grouping resources at a given time so that it is possible to effectively implement the chosen strategy and speed up the return on investment.

Worldwide, we find interesting contributions by Drucker [7], Kotter and Cohen [8], Heffernan [9], Hodges [10], Burnes [11], Dawson and Andriopoulos [12], McGrath and Bates [13], Armenakis and Bedeian [14], Masood and Kern [15], Kim and Choi [16], Ma Jiang and Liu [17] French, Sherwood and Bradford [18], Schmuckler [19], Frankenhoff and Grager [20], Darmon [21] and many others.

Armenakis and Bedeian [14] examine theoretical and empirical organizational change through four research areas. The research areas concern content, context, process, and criterion. Content issues focus on the essence of current organizational changes. Context issues focus on the forces or conditions that exist in the external and internal environment of the organization. Process issues concern the actions taken during the implementation of the intended change. Criterion issues concern the results normally assessed within the context of organizational change efforts. The authors also draw attention to the monitoring of affective and behavioural responses to change and the dynamics of current requirements in the workplace.

Kotter and Cohen [8] defined eight stages of successful large-scale change: increase urgency; build the guiding team; get the vision right; communicate for buy-in; empower action; create short-term wins; don't let up; and make change stick. Although the individual steps look simple, none is worth skipping. Kotter writes about evoking a sense of urgency. If a company has the right people, then under certain circumstances there may be a sense of urgency for change almost as a team. Kotter also points out the core of the problem, which is how to change people's behaviour. Behavioural change happens in highly successful situations mostly by speaking to people's feelings and emotions.

Several Bachelor's and Master's theses have focused on this issue, most often reflecting on a situation in a selected company. However, research focused on the Czech Republic is still lacking. This contribution was created within the newly included subject of change management in the field of study Business Economics at the Department of

\footnotetext{
* Corresponding author: jambal@mail.vstecb.cz
} 
Management of the Institute of Technology and Business in Ceske Budejovice. The aim of this contribution is to examine the content and contextual issues of organizational change in companies in the Czech Republic.

\section{Methodology}

The research was carried out in cooperation with students of the Institute of Technology and Business in České Budějovice from 28 April 2019 to 28 May 2019 with the intention of increasing the quality of subjects in the field of Business Economics, involving students in research, and obtaining data usable for the creative activities of teachers and students. Students obtained data for the whole of the Czech Republic via an online questionnaire survey:

https://docs.google.com/forms/d/e/1FAIpQLSffbC5y2QswGtNWSEbTzAu8pA8xBVyxWq27ebBvSZgCq5FyA/viewfo rm?usp=sf_link

In total, results were obtained from 433 respondents or managers of companies. The questionnaire consisted of 4 parts: a) general change management in the company; b) aspects of change in relation to corporate culture; c) characterization of changes within the company; d) identification data about the company. For this article, only the data from the first and last parts of the questionnaire are used.

To describe the general management of change from different perspectives, 18 statements were put forward, which the respondents evaluated on a five-point scale. The purpose of doing this was to objectively characterize the statements and statistically evaluate them using averages and distributions of their absolute and relative frequencies. In addition, it enabled the introduction and evaluation of a quantity (so-called "changeability" variable) for describing the general tendency to implement business changes. For "changeability", a variable was taken that is equal to the average evaluation of all 18 statements. To evaluate the changeability variable, its numerical characteristics, graphical course (boxplot diagram and histogram), and analysis of its dependence on the identification variables obtained in part d) were used.

Basic methods of descriptive and inductive statistics, including statistical tests, conditional numerical characteristics and analysis of variance, were used to obtain the results. Statistical analyses were performed in Excel and R [22, 23].

Testing statistical hypotheses is one of the basic methods of statistical induction and one of the simplest methods of quantitative decision theory. When solving a test problem, we look for answers to questions such as: Does smoking cause cancer? A statistical hypothesis is a statement about the parameters of a basic set or about the parameters of multiple sets. We call the statistical hypothesis test the procedure by which, on the basis of the results obtained from a random sample, we verify whether the statistical hypothesis about the population can be considered correct or not. The procedure of statistical testing is as follows: formulation of hypotheses; selection of test criterion and its distribution; choice of significance level; the definition of the critical field; calculation of test criterion value from measured values; and formulation of test conclusion and its factual interpretation.

In order to test the null hypothesis against the alternative, we must choose the test statistics and the critical value. We oppose the null hypothesis $\mathrm{H}_{0}: \Theta=\Theta_{0}$ and the alternative hypothesis $\mathrm{H}_{1}: \Theta \neq \Theta_{0}\left(\right.$ or $\left.\mathrm{H}_{\mathrm{a}}\right)$, where $\Theta_{0}$ is the hypothetical value of the parameter [23].

\section{Results and Discussion}

For the following claims, a score of consent from 1 to 5 points was given. 1 means strongly disagree; 2 rather disagree; 3 neutral positions; 4 tend to agree and 5 strongly agree.

Table 1. General statements on the state of change in the company

\begin{tabular}{|l|l|c|}
\hline C01 & \multicolumn{1}{|c|}{ Claim } & Average score \\
painful changes & 2.87 \\
\hline C02 & The sense of urgency of the need for change is greater than 10 years ago & 3.60 \\
\hline C03 & The sense of urgency of the need for change is greater than 5 years ago & 3.52 \\
\hline C04 & The sense of urgency of the need for change is greater than a year ago & 3.15 \\
\hline C05 & We have to deal with the effects of strong macroeconomic influences & 3.26 \\
\hline C06 & We have to deal with strong local competitive influences & 3.41 \\
\hline C07 & We have to deal with strong international competitive influences & 3.15 \\
\hline C08 & We have to deal with strong customer influences & 3.66 \\
\hline C09 & We have to deal with strong supply influences & 3.21 \\
\hline
\end{tabular}




\begin{tabular}{|l|l|c|}
\hline & \multicolumn{1}{|c|}{ Claim } & Average score \\
\hline C10 & We have to deal with the effects of globalization in the industry & 3.23 \\
\hline C11 & The pressure to reduce costs is increasing & 4.06 \\
\hline C12 & The pressure to increase the quality of products and services is increasing & 4.13 \\
\hline C13 & The pressure to increase productivity is increasing. & 4.10 \\
\hline C14 & The pressure to reduce waste of production resources is stronger than before. & 3.77 \\
\hline C15 & The pressure to reduce personnel costs is stronger than before. & 3.42 \\
\hline C16 & The pressure to look for new business development opportunities is greater than before. & 2.94 \\
\hline C17 & Management prioritizes radical changes. & 3.46 \\
\hline C18 & Management prioritizes incremental improvements. & \\
\hline
\end{tabular}

Source: Authors.

Claim CO1 examines whether companies are undergoing critical changes. This average rating is the lowest (2.87) of all. 198 respondents $(45.73 \%)$ answered strongly or rather disagree, 76 respondents $(17.55 \%)$ had a neutral attitude and 159 respondents $(36.72 \%)$ answered rather or strongly agree.

Claims CO2 - CO4 examines the urgency of changes over time (1 - 10 years). The value of the urgent need for change for one year is around 3, which is a neutral position. This means that the urgent need for change compared to the previous year is less than five or ten years ago.

Table 2. Urgency of the need for change over time in absolute and percentage frequency

\begin{tabular}{|c|c|c|c|c|c|c|}
\hline & $\mathbf{1}$ & $\mathbf{2}$ & $\mathbf{3}$ & $\mathbf{4}$ & $\mathbf{5}$ & Median \\
\hline $\begin{array}{c}\text { The urgency of the need for } \\
\text { change is greater than 10 } \\
\text { years ago }\end{array}$ & $\begin{array}{c}18 \\
(4.16 \%)\end{array}$ & $\begin{array}{c}76 \\
(17.55 \%)\end{array}$ & $\begin{array}{c}78 \\
(18.01 \%)\end{array}$ & $\begin{array}{c}151 \\
(34.87 \%)\end{array}$ & $\begin{array}{c}110 \\
(25.40 \%)\end{array}$ & 4 \\
\hline $\begin{array}{c}\text { The urgency of the need for } \\
\text { change is greater than 5 } \\
\text { years ago }\end{array}$ & $\begin{array}{c}16 \\
(3.69 \%)\end{array}$ & $\begin{array}{c}66 \\
(15.24 \%)\end{array}$ & $\begin{array}{c}91 \\
(21.02 \%)\end{array}$ & $\begin{array}{c}197 \\
(45.49 \%)\end{array}$ & $\begin{array}{c}63 \\
(14.55 \%)\end{array}$ & 4 \\
\hline $\begin{array}{c}\text { The urgency of the need for } \\
\text { change is greater than a year } \\
\text { ago }\end{array}$ & $\begin{array}{c}24 \\
(5.54 \%)\end{array}$ & $\begin{array}{c}101 \\
(23.32 \%)\end{array}$ & $\begin{array}{c}126 \\
(29.10 \%)\end{array}$ & $\begin{array}{c}148 \\
(34.18 \%)\end{array}$ & $\begin{array}{c}34 \\
(7.85 \%)\end{array}$ & 3 \\
\hline
\end{tabular}

Source: Authors.

Claims C05 - C16 concerned environmental influences and claims C17 - C18 management's preference for fundamental versus gradual change. The managements' of the companies prefer $(61.43 \%)$ gradual change, with only $30.71 \%$ of respondents indicating they prefer radical change. If the average values of the individual influences are ranked, the following results are obtained: increasing the quality of products and services (4.13); productivity growth (4.10); reducing costs (4.06); reducing waste of production resources (3.77); finding new business development opportunities and customer influence (3.66); reduction of personnel costs (3.42); the action of local competitors (3.41); macroeconomic influences (3.26); globalization in the field (3.23); supplier influence (3.21); and international competitive influences (3.15).

The following graph shows the evaluation of the individual change management questions on a scale of 1 to 5 . 


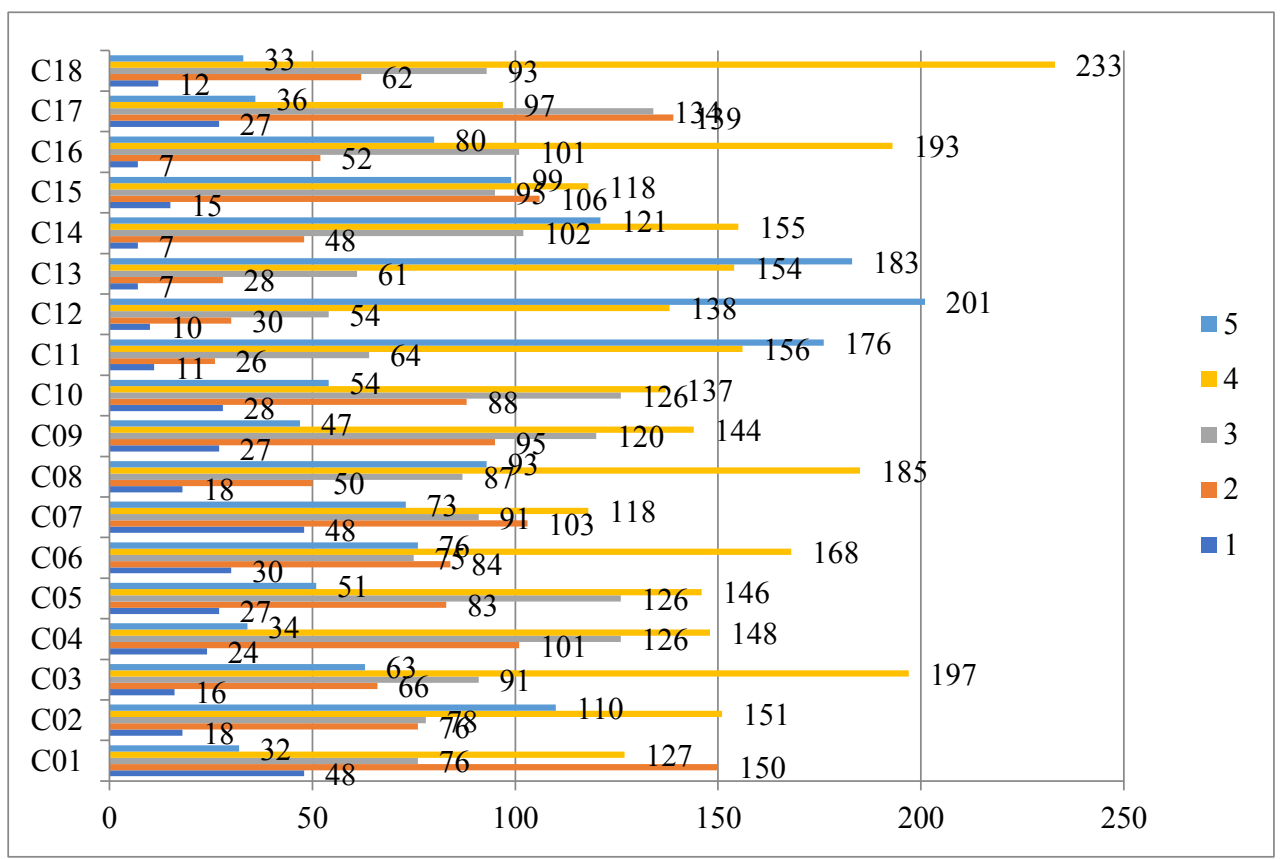

Figure 1. Evaluation of individual statements about change management

Source: Authors.

By averaging the point evaluations for the individual evaluation statements about the management of changes in the companies, a variable was generated, which we have chosen to call the "changeability" variable.

\subsection{Numerical characteristics of the changeability variable}

The numerical characteristics of the changeability variable are given in the following tables.

Table 3. Numerical characteristics of the changeability variable

\begin{tabular}{|l|c|}
\hline Characteristics & Changeability \\
\hline Average & 3.480113 \\
\hline Median & 3.555556 \\
\hline Standard deviation & 0.5465154 \\
\hline Interquartile range IQR & 0.6666667 \\
\hline Coefficient of Variation & 0.1570396 \\
\hline Minimum & 1.333333 \\
\hline Maximum & 4.777778 \\
\hline
\end{tabular}

Source: Authors.

The Shapiro-Wilk test was subsequently applied to determine whether the variability of the changeability variable has a normal distribution. The results were: $\mathrm{W}=0.9744$; $\mathrm{p}$-value $=6.624 * 10-7$. This means that the data are not normally distributed at the $5 \%$ level of significance. This is also clear from the boxplot diagram and histogram in Figure 2. 


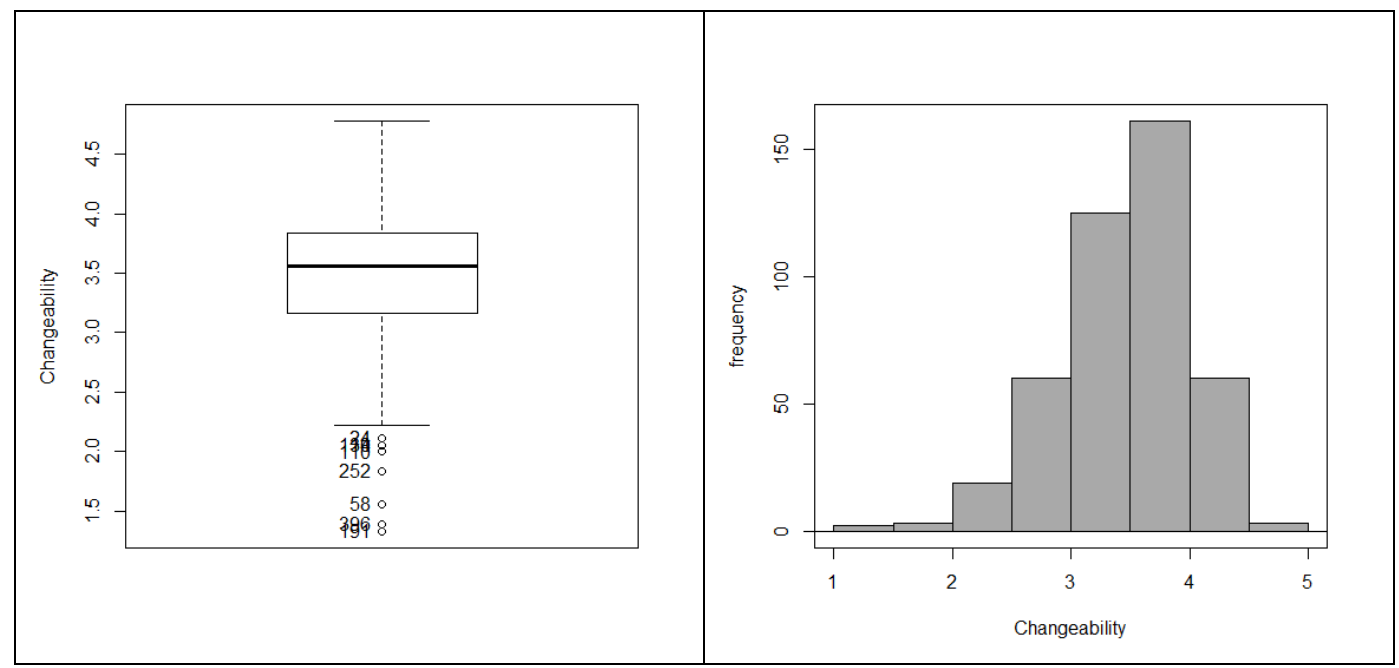

Figure 2. Boxplot and histogram of the changeability variable

Source: Authors.

It is therefore possible to use an asymptotic one-sample test for the population average of the changeability variable. At the 5\% level of significance, the null hypothesis was tested to see whether the population average of changeability is equal to 3 (centre of all possible scores). The resulting p-value was $2.2 * 10^{-16}$, which means that the null hypothesis is rejected. The sample average of changeability is 3.48 points and with $95 \%$ confidence is located between 3.428 points and 3.532 points.

\subsection{Dependence of changeability variable on identification variables}

Analysis of variance can be used to verify the dependence of the changeability variable on the form of the enterprise, industry, number of employees, and place of business. The results from the ANOVA tables are summarized in Table 4, where $\mathrm{F}$ is the value of the test statistic, Df is the degree of freedom, $\mathrm{P}$ is the p-value of the F-test.

Table 4. Analysis of the dependence of the changeability variable on identification variables

\begin{tabular}{|l|c|c|c|}
\hline & \multicolumn{3}{|c|}{ Changeability } \\
\hline Factor & F value & Df & P \\
\hline Form of enterprise & 2.970 & 7 & 0.00512 \\
\hline Industry & 2.604 & 12 & 0.00235 \\
\hline Number of employees & 12.060 & 3 & $1.36^{*} 10^{-7}$ \\
\hline Place of business & 2.196 & 13 & 0.00912 \\
\hline
\end{tabular}

Source: Authors.

At the 5\% level of significance, the statistically significant dependence on the variables form of enterprise, industry, number of employees, and place of business was demonstrated. This is also confirmed by the tables of characteristics, where the contingent mean values vary considerably depending on the number of employees.

Tables 5 to 8 show the numerical characteristics of the changeability variable for variability according to form of enterprise, industry, the number of employees, and place of business.

Table 5. Numerical characteristics of the changeability variable by form of enterprise

\begin{tabular}{|l|c|c|c|}
\hline Form of enterprise & Mean & Standard deviation & data n \\
\hline Joint-stock company & 3.604762 & 0.4955206 & 140 \\
\hline Cooperative & 3.477778 & 0.4886924 & 10 \\
\hline Other & 3.444444 & 0.5241101 & 7 \\
\hline Another trading company & 3.477778 & 0.3586915 & 15 \\
\hline Self-employed & 3.318182 & 0.5121056 & 22 \\
\hline Contributory and budgetary organization & 3.500000 & 0.4297794 & 14 \\
\hline Limited liability company & 3.462281 & 0.5717998 & 190 \\
\hline State enterprise & 3.180952 & 0.633366 & 35 \\
\hline
\end{tabular}

Source: Authors. 
Table 6. Numerical characteristics of the changeability variable by industry

\begin{tabular}{|l|c|c|c|}
\hline Industry & Mean & Standard deviation & data n \\
\hline Tourism & 3.401961 & 0.5930180 & 17 \\
\hline Transport and logistics & 3.440898 & 0.5751851 & 47 \\
\hline Finance & 3.138889 & 1.2177950 & 2 \\
\hline Other & 3.488889 & 0.5420583 & 5 \\
\hline Marketing & 2.666667 & 0.5499719 & 2 \\
\hline Trade & 3.515432 & 0.5337173 & 90 \\
\hline Food production & 3.629630 & 0.6789001 & 3 \\
\hline Industry & 3.621176 & 0.4751761 & 138 \\
\hline Services & 3.359903 & 0.6302419 & 69 \\
\hline State administration and self-government & 3.406907 & 0.4822028 & 37 \\
\hline Building and construction & 2.953704 & 0.4613676 & 6 \\
\hline Education & 3.58889 & 0.5085686 & 5 \\
\hline Agriculture & 3.143519 & 0.3815750 & 12 \\
\hline
\end{tabular}

Source: Authors.

Table 7. Numerical characteristics of the changeability variable by number of employees

\begin{tabular}{|l|c|c|c|}
\hline Number of employees & Mean & Standard deviation & data n \\
\hline $0-9$ & 3.048246 & 0.7137025 & 38 \\
\hline $10-49$ & 3.449954 & 0.5241790 & 121 \\
\hline $50-249$ & 3.484634 & 0.5050497 & 141 \\
\hline 250 and more & 3.626149 & 0.4882231 & 133 \\
\hline
\end{tabular}

Source: Authors.

Table 8. Numerical characteristics of the changeability variable by location of business

\begin{tabular}{|l|c|c|c|}
\hline Place of business & Mean & Standard deviation & data n \\
\hline Prague & 3.376296 & 0.51935939 & 75 \\
\hline South Bohemian Region & 3.452540 & 0.55489262 & 199 \\
\hline South-Moravian Region & 3.702381 & 0.31016886 & 14 \\
\hline Karlovy Vary Region & 3.500000 & 0.83296288 & 6 \\
\hline Vysocina Region & 3.563973 & 0.39163741 & 23 \\
\hline Karlovy Vary Region & 3.722222 & 0.07856742 & 2 \\
\hline Liberec Region & 2.388889 & 1.49278098 & 2 \\
\hline Moravian-Silesian Region & 2.638889 & 0.43212081 & 2 \\
\hline Olomouc Region & 3.338889 & 0.43212081 & 7 \\
\hline Pardubice Region & 3.261905 & 0.39246279 & 39 \\
\hline Pilsen Region & 3.561254 & 0.55815108 & 46 \\
\hline Central Bohemian Region & 3.676329 & 0.52578302 & 5 \\
\hline Usti Region & 3.388889 & NA & 1 \\
\hline Zlín Region & 3.433333 & 0.78015510 & \\
\hline
\end{tabular}

Source: Authors

\section{Conclusion}

From the evaluation of the individual statements in part a) we can see that: the first statement "Our organization is going through a number of serious and often painful changes" is the least evaluated; the urgency of the need for change compared to the previous year is less than five or ten years ago; the management of the company prefers gradual changes; from the effect of individual influences, the increase in the quality of products (services) is rated the highest, and international competitive influences are rated the lowest. These results are also confirmed by the graph of the frequency distribution in terms of the predominance of positive or negative evaluations.

The changeability variable, describing the tendency to undertake change, ranges from 1.3 to 3.8 points, is homogeneous and has a slightly asymmetric distribution with a significant shift of the mean to a more positive value, with a mean distribution of 3.48 points. Its values depend significantly on all the identification variables used, mostly on the number of employees of the company and the industry in which it operates, and less so on the form of the enterprise and place of business.

\section{References}

1. Z. Častorál, Strategic management of change and knowledge. Prague: Jan Amos Comenius University (2010)

2. L. Kubickova, K. Rais, Change management in companies and other organizations. Prague: Grada (2012) 
3. R. Machan, Change management. $2^{\text {nd }}$ ed. Prague: University of Economics and Management (2013)

4. J. Veber, Innovation management. Prague: Management Press (2016)

5. P. Řehoř, Change management. Ceske Budejovice: University of South Bohemia in Ceske Budejovice (2016)

6. M. Bauer, I. Haburiová, Leadership using kaizen and lean: fairy tales for tired managers. Brno: BizBooks (2015)

7. P. F. Drucker, Management in a time of great change. Prague: Management Press (1998)

8. J. P. Kotler, D.S. Cohen, The Heart of Change: Real Stories of How People Change Their Organizations. Prague: Management Press. (2003)

9. M. Heffernan, Beyondmeasure: the big impact of small changes. London: Ted Books, Simon \& Schuster (2015)

10. J. Hodges, Managing and leading people through organizational change: the theory and practice of sustaining change through people. Philadelphia: Kogan Page (2016)

11. B. Burnes, Managing Change. $7^{\text {th }}$ ed. New York: Pearson (2017)

12. P. Dawson, C. Andriopoulos, Managing Change, Creativity and Innovation. $3^{\text {rd }}$ ed. London: Sage Publications Ltd. (2017)

13. J. McGrath, B. Bates, 89 most important management theories for practice. Prague: Management Press (2015)

14. A. Armenakis, A. Bedeian, Organizational change: A review of theory and research in the 1990s. Journal of Management. 25(3), 293-315 (1999)

15. T. Masood, M. Kern, J. Clarkson, Characteristics of changeable systems across value chains. International Journal of Production Research. (2020)

16. J. Kim, S. O. Choi, The intensity of organizational change and the perception of organizational innovativeness; with discussion on open innovation. Journal of Open Innovation: Technology, Market, and Complexity. 6(3) (2020)

17. S. Ma, Z. Jiang, W. Liu, A design change analysis model as a change impact analysis basis for semantic design change management. Proceedings of the Institution of Mechanical Engineers, Part C: Journal of Mechanical Engineering Science. 231(13), 2384-2397 (2017)

18. J. R. French, J. J. Sherwood, D. L. Bradford, Change in Self-identity in a Management Training Conference. The Journal of Applied Behavioral Science. 2(2), 210-218 (1966)

19. E. Schmuckler, How to move in Management - Executives guide to changing Jobs. Personal psychology. 20(3), 362-363 (1967)

20. W. P. Frankenhoff, Ch. Granger, Strategic Management - New managerial concept for an era of rapid change. Long range planning. 3(3), 7-13 (1971)

21. R. Y. Darmon, Leading the sales force: A dynamic management process. Cambridge: Cambridge University Press (2007)

22. J. Stuchlý, J. Jambal, Customer evaluation of loyalty programs in selected companies of the South Bohemian region. SHS Web of Conferences - Innovative Economic Symposium 2018 (IES2018): Milestones and Trends of World Economy. (2019)

23. J. Stuchly, Statistical data analysis: study support for full-time and combined study: bachelor's study program. Ceske Budejovice: VSTE (2015) 